\title{
Neuroectodermal melanolysosomal disease
}

INSERM

\section{Source}

INSERM. (1999). Orphanet: an online rare disease and orphan drug data base.

Neuroectodermal melanolysosomal disease. ORPHA:33445

Elejalde syndrome (ES) is characterized by silvery to leaden hair, bronze skin colour in sunexposed areas and severe neurological impairment. 